\title{
O Problema do Trabalho Infantil na Agricultura familiar: o caso da produção de tabaco em Agudo-RS ${ }^{1}$
}

\author{
Joel Orlando Bevilaqua Marin², Sergio Schneider ${ }^{3}$, \\ Rafaela Vendruscolo ${ }^{4}$ e Carolina Braz de Castilho e Silva ${ }^{5}$
}

\begin{abstract}
Resumo: O objetivo do artigo é analisar a emergência do problema do trabalho infantil no cultivo de tabaco em Agudo, desencadeado pela promulgação do Decreto n. 6.481/2008, que trata das piores formas de trabalho infantil. Os procedimentos metodológicos utilizados foram a revisão bibliográfica, pesquisa documental e um estudo de caso, realizado no município de Agudo, Rio Grande do Sul. No estudo de caso, procurou-se obter dados quantitativos e qualitativos, por meio de questionários e entrevistas abertas, dirigidos para 27 agricultores familiares fumicultores, com filhos com menos de 18 anos de idade. Os resultados da pesquisa indicam a existência de um confronto entre diferentes concepções sobre o trabalho da criança no âmbito da agricultura familiar. Os dispositivos legais, os termos de compromissos e os contratos de integração na cadeia produtiva do fumo proíbem o trabalho de menores de 18 anos, fundamentando-se nos princípios internacionais da garantia do pleno desenvolvimento das crianças. $\mathrm{Na}$ perspectiva das famílias, o trabalho das crianças é entendido como "ajuda", forma de socialização e formação dos herdeiros. Portanto, os pais não concordam que se trata de uma forma perversa de exploração do trabalho dos próprios filhos.
\end{abstract}

Palavras-chaves: Infância, trabalho infantil, agricultura familiar, tabaco.

Abstract: The aim of this paper is to analyze the emergence of the child labor problem in tobacco growing in Agudo (Rio Grande do Sul state), triggered by the promulgation of

1 Os autores agradecem ao CNPq pelo apoio financeiro que viabilizou a realização desta pesquisa e aos pareceristas da Revista da SOBER que avaliaram o artigo e fizeram sugestões valiosas. Também somos gratos às famílias de agricultores que responderam ao questionário da pesquisa e nos receberam em suas casas para prestarem informações sobre suas formas de trabalho e vida. As lacunas remanescentes e as opiniões expressas no artigo são de responsabilidade exclusiva dos autores.

2 Doutor em Sociologia, Professor da Universidade Federal de Santa Maria. E-mail: bevilaquamarin@gmail.com

3 PhD em Sociologia, Professor da Universidade Federal do Rio Grande do Sul. E-mail: schneide@ufrgs.br

4 Mestre em Extensão Rural, Professora do Instituto Farroupilha, São Vicente do Sul/RS. E-mail: rafasociais@yahoo.com.br

5 Mestre em Sociologia, Doutoranda no Programa de Pós-graduação em Desenvolvimento Rural, Universidade Federal do Rio Grande do Sul. E-mail: carolinabcs@yahoo.com.br 
Act 6.481/2008, which addresses the worst child labor conditions. The methodological procedures used were the literature review, desk research and a case study, conducted in the municipality of Agudo. In the case study, we have tried to obtain quantitative and qualitative data through questionnaires and open interviews directed to 27 tobacco growers, and with teenagers and children under 18 years old. The survey results indicate the existence of a clash between different conceptions of child labor in small scale family farmers. The legal devices, the commitment terms and the tobacco supply chain contracts forbid child labor below the age of 18 based on international agreements and regulations which guarantee childhood development. From the perspective of the families, child labor is understood as "help" and a way of socialization and training of the inheritor. Therefore, parents do not agree that child labor is a perverse form of labor exploitation of their children.

Key-words: Childhood, labor, family farming, tobacco growing.

Classificação JEL: J13, J28, J47, J62, J81.

\section{Introdução}

Em 2009, os contratos de integração da cadeia produtiva de tabaco em folha, firmados entre agroindústrias fumageiras e os agricultores familiares do Rio Grande do Sul, inseriram uma cláusula social que obriga o agricultor a cumprir a legislação brasileira referente a "não utilização da mão de obra infantil", mais especificamente o disposto no artigo 7, inciso XXXIII da Constituição Federal, as normas previstas no Estatuto da Criança e do Adolescente (Lei 8.069/1990), bem como toda a legislação complementar relacionada ao trabalho infantil. Essa cláusula social foi resultado de um Termo de Compromisso firmado pelas agroindústrias de fumo, do Sindicato da Indústria do Fumo da Região Sul do Brasil e a Associação dos Fumicultores do Brasil, sob a orientação do Ministério Público do Trabalho do Rio Grande do Sul. Por meio deste documento, criaram-se mecanismos para intimidar o agricultor que produz fumo no Rio Grande do Sul quanto ao uso do trabalho de crianças e adolescentes menores de 18 anos, bem como constranger os pais no sentido de manter seus filhos matriculados e com frequência regular na escola.

Os agricultores familiares e suas entidades de representação, especialmente os sindicatos vinculados à Federação dos Trabalhadores da Agricultura no Rio Grande do Sul (Fetag) e à
Federação dos Trabalhadores da Agricultura Familiar da Região Sul (Fetraf-Sul), não concordam com a categorização do "trabalho infantil" no cultivo do tabaco e repudiam as medidas punitivas recaídas sobre os pais que utilizam a "ajuda" dos filhos menores, impetradas pelos órgãos de defesa dos direitos das crianças e dos adolescentes. Sob a perspectiva das famílias de agricultores fumicultores e suas entidades de representação política, no cultivo do fumo, assim como em outras atividades produtivas e domésticas, as crianças e adolescentes "ajudam" os pais, como parte integrante do processo de socialização das novas gerações. Mais do que isso, a "ajuda" não impede a continuidade da escolarização, nem mesmo prejudica a formação e desenvolvimento físico ou pessoal.

Nota-se, portanto, a existência de diferentes concepções de infância e de trabalho em confronto. Por um lado, as concepções propugnadas pelos dispositivos legais vigentes no Brasil proíbem o trabalho da criança e do adolescente no cultivo do fumo, por entendê-lo como uma das piores formas de trabalho infantil. Por outro lado, os pais, pautados nos usos e costumes tradicionalmente empregados para socializar as novas gerações, se atribuem o dever de educar os filhos por meio do trabalho, seja nas atividades agrícolas ou domésticas, desde que não impeça ou dificulte a continuidade dos estudos escolares. 
O objetivo da pesquisa foi compreender a problemática do "trabalho infantil" na agricultura familiar brasileira, a partir do estudo de caso do cultivo do fumo no município de Agudo, estado do Rio Grande do Sul. O estudo se valeu da combinação de diferentes procedimentos metodológicos, incluindo pesquisa bibliográfica, pesquisa documental e estudo de caso. A pesquisa bibliográfica procurou levantar as principais contribuições dos estudos sociais rurais sobre os temas infância e trabalho nas unidades de produção familiar. A pesquisa documental envolveu o estudo da legislação vigente no Brasil relacionada ao trabalho infantil, com destaque para o Decreto n. 6.481/2008 que trata das piores formas de trabalho infantil, algumas delas existentes no ramo agrícola.

O estudo de caso foi realizado no município de Agudo, conjugando o levantamento de dados qualitativos e quantitativos. ${ }^{6}$ Os dados qualitativos foram obtidos por meio de entrevistas semiestruradas, dirigidas para 27 famílias de agricultores que cultivam tabaco e com filhos menores de 18 anos. A composição da amostragem foi, portanto, não probabilística, na medida em que a pesquisa visava captar as percepções dos agricultores fumicultores de Agudo sobre a questão do trabalho dos próprios filhos, em face da legislação vigente. O critério utilizado para se estabelecer o limite do número de informantes foi o da saturação da informação, isto é, quando as informações começaram a se repetir, decidiu-se concluir a realização das entrevistas. Para complementação dos dados de campo, esses mesmos agricultores responderam um questionário, composto por variáveis relacionadas à composição familiar, formação escolar, divisão do trabalho familiar, trabalho das crianças e jovens, propriedade da terra, produção agrícola e níveis de tecnificação. Os dados quantitativos coletados foram sistematizados com o auxílio do software SPSS (Statistical Package for Social

6 A realização da pesquisa de campo submeteu-se à aprovação do Comitê de Ética em Pesquisa da Universidade Federal do Rio Grande do Sul e foi realizada durante o inverno de 2010.
Sciences), facilitando a análise e apresentação dos resultados.

Os agricultores familiares de Agudo são descendentes de imigrantes alemães, que foram assentados em uma colônia na região central do Rio Grande do Sul, ainda na metade do século XIX. Desde os primórdios da colonização, os colonos alemães plantavam variedades de tabaco adequadas para a produção de fumo de corda, além de uma diversidade de cultivos de interesse mercantil ou de consumo familiar. Atualmente, o fumo e o arroz são os principais produtos agrícolas de Agudo, aquele cultivado nas terras de relevo acidentado, esse nas várzeas do Vale do Rio Jacuí. Os agricultores familiares entrevistados são donos de pequenas parcelas de terra, sendo que nove têm até 10 hectares, 13 , entre 11 e 20 hectares e cinco, entre 21 e 50 hectares, nas quais destinam uma pequena área para o cultivo do fumo. Do total, 15 agricultores destinam até três hectares para a produção de fumo, enquanto 11 utilizam entre 3,1 e 5 hectares. Somente uma família cultiva mais de 10 hectares de fumo. $\mathrm{Na}$ produção de fumo, os agricultores familiares mantêm relações contratuais com diversas agroindústrias fumageiras, com destaque para a Alliance One, Universal Leaf, CTA - Continental, Intab e Souza Cruz.

O artigo está organizado em quatro seções, além da introdução e da conclusão. Na primeira, busca-se analisar os processos de construção social da infância e do problema do trabalho infantil nas sociedades modernas. A segunda seção busca, a partir de uma pesquisa bibliográfica dos estudos sociais rurais, compreender os significados sociológicos do trabalho das crianças nas unidades de produção familiar. Na sequência, enfocam-se os processos jurídicos e sociais que levaram a categorizar como "trabalho infantil" todas as tarefas desenvolvidas por crianças e adolescentes no cultivo do tabaco no Brasil. Na última, procura-se analisar as relações estabelecidas entre infância, trabalho e escola, nos processos de socialização historicamente construídos pelos agricultores familiares fumicultores de Agudo. 


\section{A construção social da infância e do problema do trabalho infantil}

A infância é uma construção social, cujas representações transformaram-se ao longo da história e diferenciaram-se entre os grupos sociais. Segundo Ariès (1981), as concepções modernas de infância, como uma fase específica da vida dedicada aos estudos e à preparação para o futuro, foram construídas a partir da ascensão de uma classe burguesa na Europa. A partir desse processo social, houve a necessidade de fortalecimento da família para proteger as crianças, bem como de uma maior intervenção da sociedade e do Estado para oferecer a elas escolarização, assistência e proteção. Além disso, as crianças deixaram de trabalhar para que pudessem se dedicar aos estudos e às brincadeiras.

No estudo sobre o desenvolvimento do capitalismo europeu no século XIX, Marx (1982) afirmou que a exploração da força de trabalho infantil estava estreitamente associada ao desenvolvimento industrial, na medida em que a maquinaria reduziu ou tornou dispensável a força muscular, requerendo mais qualidades específicas da agilidade e flexibilidade dos membros. Todavia, os avanços tecnológicos, associados aos movimentos da classe operária contra a exploração das crianças, resultaram na intervenção do Estado para a regulamentação de leis para proibir a exploração do trabalho infantil e criar instituições e políticas de proteção à infância. No estudo da experiência da classe trabalhadora inglesa entre os anos 1790 e 1830, Thompson (1987) afirma que as formas violentas e predatórias do uso do trabalho infantil começaram a ser problematizadas quando os Comitês pela Redução da Jornada empenharam-se na organização de campanhas entre os operários. Mas a saída da criança do universo da fábrica tornou-se palco de grandes disputas, porque estavam em jogo múltiplos e contraditórios interesses econômicos, valores, tradições e concepções de mundo, defendidos pelos industriais, famílias, agentes do Estado, religiosos.

Com os movimentos sociais contra a exploração do trabalho infantil, as crianças das classes trabalhadoras da Europa também foram encaminhadas para a escola, por ser reconhecida, ao lado da família, como a instituição privilegiada para a socialização da infância. Com isso, desenvolveram-se diversas leis, conhecimentos nas áreas da saúde, pedagogia e psicologia, bem como instituições educativas e de proteção da infância, distribuindo responsabilidades para família, sociedade e Estado, no sentido de garantir o desenvolvimento integral das crianças. Assim, o direito a uma infância livre do trabalho passou a ser direito de todas as crianças, independente da classe social, idade, gênero, etnia e religião.

Se na Europa as crianças saíam das fábricas para serem matriculadas nas escolas, no Brasil, nos primórdios da industrialização, as crianças passaram a ocupar os empregos dos adultos tendo seus salários rebaixados. Além dos salários aviltados pagos às crianças trabalhadoras, havia perigos constantes de acidentes, danos à saúde e prejuízos para o processo de escolarização. Mesmo assim, o trabalho era valorizado como meio de complementação da renda familiar, de disciplinarização das crianças e como alternativa para evitar a delinquência (ALVIM, 1984; MOURA, 1991).

De acordo com Marin e Marin (2008), a concepção de infância como uma idade da vida que requer proteção dos adultos e que precisa ser poupada do trabalho, foi internacionalizada a partir do século XX, especialmente após a Segunda Guerra Mundial, pela intervenção de organizações internacionais de defesa dos direitos das crianças como a Organização das Nações Unidas (ONU), o Fundo das Nações Unidas para a Infância (Unicef) e a Organização Internacional do Trabalho (OIT). Por meio da proposição de um conjunto de doutrinas e de políticas públicas, estas organizações internacionais procuram difundir as concepções burguesas de infância, os direitos da criança e o aparato de regulação do trabalho infantil, socialmente construídos nos países desenvolvidos. As crianças são percebidas como pessoas em condições especiais de desenvolvimento, sujeitos de direitos próprios, com direitos de capacitação adequada e necessidades 
de proteção diferenciada, específica e integral. Construídas e positivadas nas legislações dos países desenvolvidos, tais concepções de infância são universalizadas pela atuação incisiva dos organismos internacionais.

A Constituição de 1934, referendada pelas Constituições de 1937 e 1946 e pela Consolidação das Leis do Trabalho, buscou proibir a exploração do trabalho infantil, ao estabelecer os 14 anos como a idade mínima para o ingresso na força de trabalho. Na faixa entre 14 e 18 anos, as condições de trabalho foram regidas por regulamentos específicos, visando controlar o uso desta força de trabalho. O trabalho noturno foi interditado para menores de 16 anos e, nas indústrias insalubres, aos menores de 18 anos e às mulheres. Desta maneira, concepções de infância e adolescência socialmente construídas em países desenvolvidos passaram a influenciar a legislação nacional, no sentido de preservar as crianças e os adolescentes do uso predatório e indiscriminado de sua força de trabalho. A infância passou a ser entendida como idade da vida em que a criança teria o direito ao não trabalho, para possibilitar-lhe o desenvolvimento físico e intelectual. A adolescência, enquanto fase transitória entre a infância e a vida adulta, também necessitava de condições especiais para garantir o pleno desenvolvimento físico-intelectual e a preparação para a entrada no mundo do trabalho.

Importante se faz salientar que os legisladores preocuparam-se em regulamentar o uso do trabalho infanto-juvenil na medida em que as crianças e os adolescentes ingressavam no mercado de trabalho assalariado. Em relação ao trabalho das crianças, amplamente utilizado nas unidades de produção familiar, incluindo as agrícolas, não havia qualquer legislação regulamentadora para definir idade para o ingresso ou condições para o uso desta força de trabalho. Os legisladores concebiam o trabalho infantil no bojo da família sob as perspectivas educativas e integradoras da criança ao mundo dos adultos, sendo este trabalho entendido como uma ajuda da criança e do jovem à manutenção da família e ao bom andamento da unidade de produção e consumo.
Por isso, havia um consenso social de que nas unidades de produção familiares não havia exploração do trabalho das crianças. Antes, o ato de trabalhar tinha funções socializantes das novas gerações para a vida adulta.

\section{O trabalho da criança nas unidades de produção familiar}

De acordo com Marin e Vendruscolo (2010), os diversos autores que estudaram as sociedades camponesas no Brasil destacaram a importância do trabalho na transmissão do patrimônio de práticas, habilidades e saberes historicamente acumulados. A formação profissional e a construção do herdeiro exigiam que as crianças fossem iniciadas no trabalho, sob a orientação dos pais ou dos trabalhadores adultos, como parte do processo de socialização profissional e ritualização da passagem para a idade adulta. Conforme a idade, o sexo e a força física, as crianças incorporavam-se às atividades produtivas e reprodutivas das famílias, na condição de ajudante. As gerações mais velhas atribuíam ao trabalho das crianças um significado primordial em sua socialização, uma vez que elas se preparavam para tornar-se os futuros agricultores ou donas de casa, assim como seus pais. Nessa perspectiva, o trabalho das crianças assumia um caráter fundamental no ciclo da formação intergeracional dos camponeses.

Candido (1987), em seu clássico Parceiros do Rio Bonito, fornece elementos sobre os processos de socialização da infância no meio rural. No agrupamento de camponeses do município de Bofete, estado de São Paulo, desde pequenos, os filhos acompanhavam os trabalhos dos pais para incorporar a experiência acumulada sobre as técnicas agrícolas e artesanais, o trato dos animais e os serviços domésticos. Assim, o trabalho da criança, além de representar uma ajuda para garantir o sustento da unidade familiar, era reconhecido como momento de formação e preparação para a reprodução do modo de vida caipira. Para este grupo, a família e a comunidade local representam os principais espaços de socia- 
bilidade e de transmissão do conhecimento necessário para a sobrevivência e reprodução, que é mais significativo que o conhecimento da escola no interior das restritas relações comunitárias.

A partir dos dados fornecidos pelo censo do IBGE de 1950 e das Inspetorias Regionais de Estatística, Caldeira (1960) constatou que o trabalho das crianças, muitas vezes categorizado como ajuda, dificultava ou impossibilitava a continuidade da escolarização, em virtude da difícil conciliação do trabalho com o calendário escolar. O autor identificou um problema de ordem histórica e estrutural na sociedade brasileira, que perpassava todas as situações analisadas: a questão central da educação rural estava associada à pobreza da população, que, movida pela necessidade, era obrigada a requisitar a ajuda da criança. Assim, escolarização e trabalho eram incompatíveis, uma vez que a criança tinha dificuldade de coadunar as exigências da ajuda na família com o calendário escolar.

Ao analisar as relações no interior das unidades de produção familiar, Queiroz (1967) concluiu que o trabalho das crianças e adolescentes estava relacionado às precárias condições dos sitiantes, que tornava necessária a incorporação da mão de obra infantil. No contexto da década de 1960, a família numerosa possibilitava que o meeiro assumisse maior quantidade de terra aos seus cuidados, acentuando a importância da relação das crianças com a força de trabalho da unidade familiar. A melhoria das condições de trabalho e vida no meio rural relacionada à quantidade de filhos em condições de trabalhar também foi salientada por Fukui (1979), a partir do estudo das relações de parentesco e família entre os sitiantes tradicionais do interior de São Paulo e do sertão da Bahia.

A problemática do trabalho infanto-juvenil no meio rural brasileiro adquiriu centralidade no estudo de Antuniassi (1983), ao destacar os vários tipos de trabalho infanto-juvenil no meio rural, inclusive nas unidades de produção familiar, e suas implicações no processo de escolarização das crianças. No contexto rural paulista dos anos 70, ao lado do trabalho familiar socialmente valorizado, expandia-se o trabalho assalariado, caracterizado pela incorporação precoce da criança à força produtiva, em jornadas prolongadas, em franco prejuízo da escolarização. Na unidade agrícola familiar, a participação da criança na unidade de trabalho familiar liberava os adultos para que se incorporassem ao contingente de trabalhadores assalariados temporários.

Para entender a problemática da educação e do trabalho no meio rural, Martins (1975) propõe como perspectiva de análise as representações dos próprios camponeses. Partindo do estudo de diferentes grupos sociais de São Paulo, o autor afirma que a valorização da escola no meio rural tem estreitas relações com as condições históricas do trabalho produtivo, associadas à produção de mercadorias e à economia de excedentes. Nas unidades de produção inseridas em relações mercantis, a escola era valorizada na medida em que o domínio da leitura, da escrita, das operações matemáticas e de outros conhecimentos transformava-se em instrumento necessário para se inserir em relações da circulação de mercadorias e possibilitar a defesa dos próprios interesses sociais. No âmbito da economia de excedentes, em que o processo produtivo estava orientado preponderantemente à produção de bens de uso, os conteúdos repassados pela escola assumiam pouca importância, e as aspirações em relação à escola se restringiam apenas a ler, escrever e fazer contas.

Garcia Jr. (1983), ao analisar as relações no interior da unidade de produção familiar em Pernambuco, observa que, mesmo que haja uma hierarquia masculina, que carrega a responsabilidade do sustento da família, o trabalho de todos os membros da família é requisitado constantemente no roçado, de onde provém o alimento para o consumo. Neste local, o trabalho das crianças era considerado ajuda ao pai, que determina a necessidade de solidariedade dos filhos. Ajuda que também é requisitada pelos espaços domésticos de responsabilidade da mãe.

Santos (1984) também observou a vivência das crianças nas diversas tarefas da unidade de produção familiar no interior do Rio Grande do Sul. 
No contexto dos colonos produtores de uva, as crianças dividem seu tempo entre a escola e o trabalho na roça ou nos afazeres domésticos, no turno inverso ou integralmente mesmo em épocas em que o ano agrícola coincide com o calendário escolar. A socialização das crianças ocorre no interior da unidade familiar, onde o trabalho é internalizado como valor, forma de aprendizado, ajuda e distração. Assim, o trabalho entrava na ordem natural do mundo infantil, por meio do incentivo, do prêmio e, às vezes, da punição.

No município de Itapuranga, interior de Goiás, Brandão (1994) destaca a precoce inserção da criança no universo do trabalho entre os camponeses em virtude da necessidade de mão de obra, tanto nas atividades agrícolas quanto domésticas, as quais o trabalho assalariado acarretaria uma elevação nos custos de produção, assim como parte dos trabalhos pode ser realizado por crianças e adolescentes com melhor rendimento. Assim, segundo Brandão (1994, p. 123), "não é sequer imaginada a possibilidade de uma criança após os seis anos (quando não antes) não ser pouco a pouco incorporada às atividades de trabalho e produção da família". Desta maneira, existe uma complementaridade do trabalho da criança no universo familiar que conduz à autonomia no núcleo frente ao trabalho externo e à diminuição dos custos de produção nas unidades camponesas.

Em outro estudo, Martins (1991) procurou compreender como diferentes grupos sociais percebem a infância, a partir da própria fala das crianças, filhos de gaúchos migrantes de Mato Grosso e de posseiros do Maranhão. Entre os filhos de gaúchos migrantes, sob um contexto familiar de busca por condições de reprodução da unidade familiar, a terra assumia um papel simbólico, presente no imaginário das crianças, como provedora do "futuro". Símbolo também reconhecido pelos filhos de posseiros do interior do Maranhão, mas sob as condições de constante ameaça de expulsão pelos grileiros ou fazendeiros. Mesmo sob diferentes representações sobre a terra, as crianças, em ambos os casos, vivenciam responsabilidades dos adultos e participam da força de trabalho. Contudo, para os migrantes gaúchos, a terra e o trabalho representam a garantia de reprodução social das novas gerações. Para os posseiros, não há herança que justifique o trabalho infantil, mas as crianças trabalham pela necessidade de sobreviver. Além disso, vivem a realidade de expulsão e de constantes migrações em busca de um lugar melhor para viver, um lugar onde possam plantar para sua subsistência, frequentemente desiludidos por não possuírem a propriedade da terra.

A preparação do herdeiro também é identificada por Woortmann e Woortmann (1997), ao analisarem o significado do trabalho na vida dos agricultores familiares no Nordeste, no início da década de 1980. Os autores compreenderam a ajuda das crianças e adolescentes como um dos processos do ritual que transforma o menino em homem e a menina em mulher. Assim, a ajuda constitui parte do ciclo de vida dos filhos de sitiantes que são herdeiros e que vão reproduzir o modo de vida camponês.

Pelos estudos das diferentes realidades empíricas, nota-se que camponeses e agricultores familiares valorizavam as virtudes do trabalho na formação das crianças e do futuro herdeiro. Historicamente, o trabalho das novas gerações no âmbito das unidades de produção familiar assumiu caráter de ajuda e de socialização. Possivelmente, os legisladores também tiveram o mesmo entendimento, uma vez que o aparato legal brasileiro não proibiu o trabalho desenvolvido pelas crianças e pelos adolescentes nas unidades de produção agrícola familiar. Como salientou Antuniassi (1983), no Brasil, assim como em outros países, o trabalho infantojuvenil vinculado à empresa familiar não teve regulamentação, sob o pressuposto de que os adultos ligados às crianças por laços de parentesco não as exploravam e nem as submetiam a trabalhos excessivos, insalubres ou perigosos.

Entretanto, mais recentemente, alguns estudos sobre a presença da criança nas atividades agrícolas passaram a interpretar a ocupação do trabalho por um determinado período, ainda que inverso ao turno escolar, como trabalho infantil. 
Nesta perspectiva de análise, vale destacar as pesquisas apoiadas pela OIT (2004) e coordenadas por Kassouf (2004). Apesar da ampliação das políticas educacionais e de combate ao trabalho infantil, a pesquisa realizada por Kassouf (2007, p. 327) constatava que, "no Brasil, dados da PNAD de 2005 mostram que ainda existem quase três milhões de crianças e jovens de cinco a 15 anos trabalhando ou 7,8\% do total nessa faixa etária, apesar de ter havido um declínio acentuado, principalmente, a partir da metade da década de 90". No Rio Grande do Sul, em específico, Kassouf (2004, p. 89-90) afirma, com base nos dados da PNAD (Pesquisa Nacional por Amostra de Domicílios) de 2001, que existiam 170 mil crianças e jovens na faixa etária entre 5 e 17 anos de idade envolvidos em atividades laborais de risco, sendo que, deste total, 54.059 (31,8\%) desempenhavam atividades na agricultura. Contudo, Kassouf (2007) alerta que o trabalho infantil não deve ser tratado como um fenômeno social homogêneo, mas um fenômeno marcado pela diversidade de situações:

diferenças de gênero, entre atividades nas áreas rural e urbana, de risco ou não, tempo integral ou parcial, no ramo agrícola, comercial, industrial, etc. devem ser analisadas separadamente, já que suas peculiaridades exigem políticas de combate diferenciadas. Além disso, os diversos fatores envolvidos com a decisão de alocação do tempo da criança para o trabalho precisam ser diferenciados. As abordagens para se tratar de aspectos culturais e de tradição familiar são distintas das de aspectos econômicos, envolvendo pobreza e das de aspectos sociais, envolvendo baixo nível educacional dos pais e falta de visão de longo prazo, por exemplo (KASSOUF, 2007, p. 346).

Sob esta perspectiva, Pontilli e Kassouf (2007) procuram estabelecer a influência das variáveis associadas a características pessoais e familiares e variáveis de infraestrutura escolar sobre os fatores frequência e atraso escolar no ensino fundamental, em áreas rurais e urbanas, nos estados de Pernambuco e São Paulo. As autoras concluíram que a escolarização perpassa por questões de gênero, na medida em que "meninos estão mais propensos a atrasarem-se nos estudos e menos dispostos a frequentarem a escola que meninas". A escolarização também é influenciada pelos critérios étnicos, pois "crianças de cor branca apresentaram maior probabilidade de frequentar a escola e menores chances de ficarem atrasadas nos estudos, se comparadas a pardos ou negros". Somam-se ainda características familiares relacionadas aos níveis de instrução e renda familiar: "a escolaridade do chefe de família e a renda familiar per capita exercem influência sobre a frequência e o atraso escolar". As autoras destacam que a melhoria das condições de infraestrutura das escolas, da qualificação e da remuneração dos professores também contribui para a frequência escolar das crianças e apontam que "os indicadores educacionais estudados são mais precários na área rural, se comparados à área urbana" (PONTILLI e KASSOUF, 2007. p. 38-39). No que tange à saúde, Nicolella, Kassouf e Barros (2008) procuram verificar se o trabalho infantil no setor agrícola afeta mais a saúde da criança do que o trabalho exercido em outros setores. A partir dos dados da Pnad 1998 e 2003, os autores concluíram que "o trabalho no campo não causa impactos distintos na saúde da criança em relação a outros setores de atividades. Esse resultado não corrobora o senso comum de que as condições de trabalho no campo são piores que na cidade. Da mesma forma, o impacto do trabalho infantil na saúde da criança é independente do setor no qual exerce uma atividade, sendo a atividade de risco ou não" (NICOLELLA, KASSOUF e BARROS, 2008, p. 697). No entanto, os autores reconhecem a necessidade de pesquisas que façam análises mais detalhadas das diferentes ocupações rurais, a fim de se conhecer as repercussões de cada atividade laboral sobre a saúde das crianças.

Outro trabalho de Kassouf (2007) é particularmente ilustrativo em relação a esta perspectiva, 
informando as diferentes abordagens e formas de se quantificar a presença do trabalho infantil, assim como suas causas, associadas à baixa renda, pobreza e baixo nível de escolaridade dos pais. De maneira geral, estes trabalhos acabam contribuindo para a categorização de trabalho infantil como algo negativo, raramente ampliando o foco para aspectos sociológicos relacionados ao modo de vida das famílias e o significado do trabalho neste universo social formado por camponeses e agricultores familiares. Kassouf (2007) salienta a maior porcentagem de trabalhadores infantis presentes nas áreas rurais em comparação com as áreas urbanas, destacando variáveis como a pobreza das famílias, a presença de infraestrutura escolar mais fraca, menor taxa de inovação tecnológica, sendo mais fácil a criança ser absorvida em trabalhos informais, principalmente nos trabalhos agrícolas familiares. Sob este prisma, Kassouf e Ferro (2004) identificaram forte presença do "trabalho infantil" no meio rural brasileiro, em determinadas atividades produtivas, sobretudo entre agricultores familiares. A partir dos dados da Pnad de 2001, as autoras identificaram presença significativa de uso da força de trabalho infantil no cultivo de produtos como o fumo, a cana-de-açúcar, verduras e frutas.

Schneider (2005), analisando um relatório da OIT (OIT, 2004) que realçava a ampla presença do trabalho infantil na agricultura familiar, procurou rebater esta compreensão mostrando que o trabalho das crianças no espaço das unidades de produção familiar deve ser entendido pelo seu caráter pedagógico e formativo, razão pela qual pode assumir o sentido e significado de uma ajuda à família. $\mathrm{O}$ autor chama a atenção para a necessidade de se diferenciar o trabalho precário, rotineiro e degradante das diversas formas de ajuda realizadas por crianças, especialmente no âmbito da agricultura familiar, tendo em vista que o auxílio das crianças nas atividades rurais constituiria uma forma de inserção social. Outros autores (NEVES, 1999; WOORTMANN e WOORTMANN, 1997) também apontam para a necessidade de uma melhor compreensão sobre as relações de trabalho na agricultura familiar, as causas e efeitos do trabalho das crianças nas unidades de produção familiar.

\section{A construção do problema do trabalho infantil no cultivo do tabaco}

No Brasil, a partir da promulgação da Constituição de 1988 e do Estatuto da Criança e do Adolescente (ECA), de 1990, estabeleceram-se medidas jurídicas para impedir a incorporação da criança no mundo do trabalho e garantir seu pleno desenvolvimento físico e social. Além disso, esses documentos legais tornam-se marcos da promoção, controle e garantia dos direitos das crianças, que balizam a adoção de políticas públicas, para a proibição e erradicação de todas as formas de trabalho infantil, em consonância com as doutrinas da ONU, Unicef e OIT. A criança passou, então, a ser percebida sob a égide da Doutrina da Proteção Integral, tal como propugnavam os organismos internacionais de defesa dos direitos da criança (MARIN, 2006). As medidas de proteção das crianças e adolescentes ocorreram também pela elevação da idade mínima para o ingresso no mercado de trabalho. Assim, a Emenda Constitucional n. 20, de dezembro de 1998, estabeleceu os 16 anos como idade mínima para o ingresso no mercado de trabalho, salvo na condição de aprendiz na faixa etária compreendida entre 14 e 16 anos. No estudo sobre a influência do aumento da idade mínima para a incorporação no mercado de trabalho, a partir de dados da Pnad de 1995 a 2003, Ferro e Kassouf (2005, p. 326) concluem que, "embora a legislação não tenha erradicado o trabalho infantil, ela contribuiu para reduzir a porcentagem de adolescentes no mercado de trabalho".

As campanhas educativas também tiveram um papel importante para a criação de uma consciência pública sobre o problema do trabalho infantil. Nos primeiros anos da década de 1990, segundo Neves (1999), diversos agentes sociais, públicos e privados, embasados em propósitos de condenação das formas perversas de 
agregação de crianças e adolescentes ao trabalho, criaram espaços e situações para o debate, a conscientização e a mobilização da sociedade em torno desse problema social. Por conseguinte, foram instituídas políticas sociais destinadas às crianças e aos adolescentes vinculados ao trabalho infantil, o que acenava com a interdição dessas atividades econômicas ilegais e indicava o encaminhamento desses agentes à escola, segundo o pressuposto de que "lugar de criança é na escola e não no trabalho".

Outras iniciativas para o combate do trabalho infantil, seja nos espaços urbanos ou rurais, foram orientadas para a transferência de recursos financeiros para as famílias pobres. Com o apoio de organizações de cooperação internacionais, o governo brasileiro instituiu o Programa de Erradicação do Trabalho Infantil (Peti), em 1996, com o objetivo de proteger a população infantojuvenil, entre 7 e 14 anos de idade, vulnerabilizada pela exploração, pobreza e exclusão social. O programa foi introduzido nas atividades que configuravam situações de extrema exploração, a exemplo das carvoarias e ervais de Mato Grosso do Sul, dos canaviais de Pernambuco e do Rio de Janeiro, do sisal e pedreiras da Bahia. Com a concessão de bolsas mensais para as famílias das crianças trabalhadoras, o programa buscava afastar as crianças e adolescentes do mercado de trabalho e criar condições para a sua permanência na escola. Além disso, procurava incentivar a apropriação de novos conhecimentos, por meio de atividades culturais, esportivas e de lazer, no período complementar ao da jornada de ensino regular. No final da década de 1990, o Programa Bolsa-Escola foi ampliado para todos os estados da Federação, para atender um número maior de famílias que viviam em situação de pobreza e que recorriam ao trabalho infantil. Dessa forma, o programa constituiu-se em um dos principais programas para combater a exploração de crianças, reduzir a pobreza e distribuir renda.

A partir de 2003, com a denominação Bolsa Família, o programa configurou-se como principal estratégia do governo de Luiz Inácio da Silva para a erradicação do trabalho infantil e combate à pobreza, por meio da transferência de renda às famílias. Assim, o Programa Bolsa Família teve crescimento considerável, totalizando 12.648 .890 de famílias beneficiárias em 2010, com renda mensal per capita de até R\$140,00. A família com renda mensal per capita entre $\mathrm{R} \$ 70,00$ e $\mathrm{R} \$ 140,00$ só pode ingressar no programa caso tenha filhos entre 0 e 17 anos de idade. A família com renda menor que $\mathrm{R} \$ 70,00$ mensais por pessoa também pode participar do Programa, independente da idade dos membros da família. Atualmente, os propósitos do Bolsa Família são ampliar a renda das famílias pobres que têm filhos em idade escolar e reduzir as situações de vulnerabilidade social das famílias que vivem na extrema pobreza (BRASIL, 2010). Na avaliação dos impactos do Programa Bolsa-Escola, a partir dos dados da Pnad 2005, Ferro e Kassouf (2005) afirmam que o programa tinha eficiência na redução do número de horas mensais de trabalho das crianças, embora os resultados do programa não fossem conclusivos no que tange à decisão dos pais em incorporar os filhos no trabalho.

Vale ressaltar que o Programa Bolsa Família também passou a atender agricultores que trabalham em regime de economia familiar, atingidos pela pobreza e vulnerabilidade (PEDREIRA, 2006; ALONSO e SANT'ANNA, 2010). Em estudo sobre as repercussões do Bolsa Família sobre os gastos de alimentos em famílias rurais, Duarte, Sampaio e Sampaio (2009, p. 917) inferem que $88 \%$ do valor obtido pelo Programa é utilizado na aquisição de alimentos, o que indica que "existe um efeito positivo das transferências monetárias sobre o consumo alimentar das famílias beneficiárias".

Nas duas últimas décadas, os investimentos no combate infantil foram orientados para as denominadas piores formas de trabalho infantil estabelecidas pela OIT, na Convenção 182, promulgada em 1999. De acordo com o artigo terceiro dessa Convenção, as piores formas de trabalho infantil compreendem:

(a) todas as formas de escravidão ou práticas análogas à escravidão, como 
venda e tráfico de crianças, sujeição por dívida, servidão, trabalho forçado ou compulsório, inclusive recrutamento forçado ou compulsório de crianças para serem utilizadas em conflitos armados; (b) utilização, demanda e oferta de criança para fins de prostituição, produção de material pornográfico ou espetáculos pornográficos; (c) utilização, demanda e oferta de criança para atividades ilícitas, particularmente para a produção e tráfico de drogas conforme definidos nos tratados internacionais pertinentes; (d) trabalhos que, por sua natureza ou pelas circunstâncias em que são executados, são susceptíveis de prejudicar a saúde, a segurança e a moral da criança.

Nota-se que a alínea " $d$ " faz referência a trabalhos prejudiciais à saúde da criança, entendida pela Convenção n. 182 como "toda pessoa menor de 18 anos de idade." O Decreto n. 6.481, de 12 de julho de 2008 - que regulamenta o terceiro e quarto artigos da Convenção 182 da OIT, aprovada pelo Decreto Legislativo n. 178, de 14 de dezembro de 1999 e promulgada pelo Decreto 3.597, de 12 de dezembro de 2000 inseriu o trabalho no fumo na lista das piores formas de trabalho infantil, por suas possíveis repercussões sobre a saúde.

O Decreto 6.481, no primeiro artigo, aprova a Lista das Piores Formas de Trabalho Infantil (Lista TIP) proposta pela OIT e, no segundo artigo, proíbe o trabalho do menor de 18 anos nas atividades previstas na Lista TIP. Nesta lista, estão especificados os Trabalhos Prejudiciais à Saúde e à Segurança que ocorrem nas atividades agrícolas, pecuária, silvicultura e exploração florestal, detalhando os trabalhos específicos da produção do fumo, algodão, sisal, cana-de-açúcar e abacaxi. Segundo a Lista TIP, as tarefas nesses cultivos representam riscos para as crianças e adolescentes decorrentes do esforço físico e posturas viciosas, exposição às poeiras orgânicas e seus contaminantes, como fungos e agrotóxicos, contato com substâncias tóxicas da própria planta, acidentes com animais peçonhentos, exposição sem proteção adequada à radiação solar, umidade, chuva, frio, acidentes com instrumentos perfuro-cortantes. As prováveis repercussões à saúde das crianças são afecções músculo-esqueléticas, pneumonoconioses, intoxicações exógenas, cânceres, bissinoses, hantaviroses, urticárias, envenenamentos, intermações, queimaduras na pele, envelhecimento precoce, câncer de pele, desidratação, doenças respiratórias, ceratoses actínicas, ferimentos e mutilações, apagamento de digitais (BRASIL, 2008).

A Lista TIP também faz referências aos riscos à saúde nas atividades de beneficiamento do fumo, sisal, castanha de caju e cana-de-açúcar, resultantes do esforço físico, levantamento e transporte de peso, exposição a poeiras orgânicas, ácidos e substâncias tóxicas, com repercussões manifestas em fadiga física, afecções músculo-esqueléticas - bursites, tendinites, dorsalgias, sinovites, tenossinovites -, intoxicações agudas e crônicas, rinite, bronquite, vômitos, dermatites ocupacionais e apagamento das digitais (BRASIL, 2008).

Isto significa que os trabalhos no fumo, tanto na produção quanto no processamento de suas folhas, representam sérios riscos à saúde que comprometem o pleno desenvolvimento das crianças. O problema do "trabalho infantil no cultivo do fumo" ganhou maior notoriedade com a ratificação da Convenção-Quadro para Controle do Tabaco (CQCT), em novembro de 2005. A CQCT é considerada o primeiro tratado internacional de saúde pública, proposto pela Organização Mundial de Saúde (OMS) e negociado por quase 200 países, entre 1990 e 2003. A partir do reconhecimento dos graves danos sanitários, sociais e econômicos decorrentes do tabagismo, esse tratado internacional busca reduzir o consumo, a comercialização e a produção do tabaco (SOUZA, 2010). No que tange à produção do tabaco, o artigo 17 propõe a implementação de medidas que viabilizem a adoção de alternativas de produção economicamente viáveis para os agentes envolvidos na produção e comercialização do tabaco. Já o artigo 18 busca responsabilizar os estados signatários para o cumprimento das 
obrigações relativas à proteção do meio ambiente e à saúde das pessoas, nas atividades de cultivo do tabaco e na fabricação de produtos de tabaco. Neste sentido, os agricultores produtores de tabaco ficaram sob a mira de diferentes documentos internacionais, ratificados pelo governo brasileiro, no sentido de reduzir o cultivo, garantir a saúde dos trabalhadores e interditar o trabalho das crianças. Por consequência, houve maior fiscalização de pais e mães no sentido de não empregar os filhos no cultivo e beneficiamento do tabaco e de encaminhá-los para a escola.

Todavia, a tendência à universalização das representações da infância - em cujo eixo mobilizam-se os diversos movimentos de moralização, conscientização e denúncia contra a exploração da força de trabalho infantil - normalmente desconsidera as especificidades dos contextos econômicos, sociais e culturais dos diversos grupos sociais em que as crianças vivem. Considerando-se que a infância é uma construção social, interessa compreender os significados de infância, do trabalho e escola nos processos de socialização dos filhos dos agricultores familiares que cultivam o tabaco.

\section{Infância, trabalho e escola entre os agricultores fumicultores de Agudo}

A representação da infância entre agricultores familiares de Agudo, que são produtores de tabaco, assume características influenciadas pela universalização das concepções de proteção à criança e ao adolescente. As ações coercitivas do Estado e das instituições econômicas, bem como a maior facilidade de acesso à escola, influenciam as representações sobre a infância no universo social e cultural dos produtores de tabaco. Todavia, alguns aspectos da sociabilidade permanecem vivos na reprodução social dos agricultores, os quais são transmitidos às novas gerações, perpassando pela valorização do trabalho no processo de formação e pelo fortalecimento das relações de solidariedade familiares.

\subsection{Os significados de infância nas gerações dos pais e filhos}

Rememorando suas infâncias, os agricultores fumicultores de Agudo destacam a importância que era atribuída ao trabalho na formação profissional e moral das crianças. Eles associam a sua própria infância como um tempo de dificuldades, de muito trabalho e de uma educação marcada pela autoridade dos adultos, que determinava as condutas das crianças e jovens. A infância compreendia um curto espaço de tempo, tendo em vista que muitos trabalhos e responsabilidades eram transferidos para as crianças, tão logo adquirissem força física e capacidade de compreender e executar tarefas. As concepções de infância em sua relação com o lúdico, a educação formal e a liberdade criativa, isenta de responsabilidades com seu sustento e trabalho, características das orientações jurídicas e do mundo burguês, não correspondiam com as relações na unidade de produção familiar da época. Nesta, o trabalho constituía-se um princípio educativo, parte da formação do futuro adulto, ao lado de uma rápida passagem pela escola, para alcançar o domínio da escrita, da leitura e das operações matemáticas.

Desta forma, o trabalho teve amplo significado na infância dos pais. Na memória dos pais de famílias de Agudo, as crianças participavam da vida da propriedade desde muito cedo. Mesmo ainda incapazes de trabalhar, elas frequentavam os ambientes de trabalho dos pais e, na medida em que adquiriam capacidade física e mental, desenvolviam algumas tarefas consideradas leves, para iniciar o processo de aprendizagem junto com os pais. Os trabalhos leves eram aquelas tarefas desenvolvidas na casa ou nos arredores dela e nas roças de subsistência. Os trabalhos domésticos e o trato com os pequenos animais, bem como capinar a horta, carregar lenha para a cozinha, dentre outros, eram os primeiros afazeres aprendidos, mas sempre percebidos pelos adultos como "ajuda". 
A solidariedade, portanto, constitui um valor presente na cultura dos agricultores familiares de Agudo, que se transfere para as novas gerações. As atividades desenvolvidas pelas crianças assumem, ainda hoje, um caráter de "ajuda" aos familiares, não sendo considerado propriamente um "trabalho". Em seu tempo, os agricultores familiares entrevistados relatam a necessidade e a obrigatoriedade da ajuda aos seus pais, como condição para a sobrevivência da unidade de produção familiar. Os pais necessitavam da mão de obra dos filhos tanto nos afazeres domésticos e nos arredores da casa, quanto nas atividades da roça, conforme a força física das crianças. Em tempos passados, as famílias eram numerosas e todos participavam da vida produtiva da propriedade, inserindo-se precocemente nas diversas atividades necessárias na propriedade familiar, em conformidade com a divisão social de gênero e a capacidade física e intelectual. $\mathrm{O}$ trabalho dos filhos tinha um papel fundamental na complementação da mão de obra familiar e uma estreita relação com o consumo familiar: "Naquela época dá pra dizer que quem comia tinha que trabalhar, hoje não mais" (agricultor familiar, 50 anos). Revela-se, assim, a necessidade da ajuda das crianças nos diversos trabalhos, a fim de garantir a continuidade da vida da família na agricultura.

Contudo, os agricultores familiares entrevistados em Agudo afirmam que houve mudanças nas concepções sobre o trabalho dos filhos. Eles garantem que, atualmente, os filhos não são obrigados a trabalhar como "antigamente", em seu tempo de infância. Os trabalhos realizados pelas crianças e adolescentes ocupam pouco tempo do dia e têm o propósito de orientar para o desenvolvimento do senso de responsabilidade, como valor fundamental para a vida em sociedade, com a observância das possibilidades físicas e mentais das crianças e adolescentes. Os trabalhos destinados aos filhos são considerados orientadores da vida em qualquer meio, que servem de aprendizado do valor do trabalho e da conquista da autonomia pessoal.
Os pais, ao confrontarem a infância por eles vivida e a infância dos filhos, facilmente concluem que os filhos gozam de maior liberdade. Eles garantem que hoje os filhos são mais poupados em relação ao trabalho, quando comparado com a obrigatoriedade do auxílio em sua época. "Agora, se as crianças não querem, a gente não obriga a fazer as coisas. No nosso tempo, não. Se os pais diziam que tinha que fazer isso, a gente ia e fazia" (Agricultora familiar, 35 anos). Num tempo pretérito, as crianças não tinham o direito de se furtar do trabalho, pois os pais impunham a obrigatoriedade do trabalho, que se exercia inclusive por meio da coerção e do castigo. Atualmente, os filhos são educados com mais liberdade: "Minha infância foi isso, menos liberdade, e os jovens hoje têm muita liberdade" (Agricultor familiar, 50 anos). A liberdade é observada de forma positiva pelos pais, quando relacionada com as maiores possibilidades de escolhas concedidas aos filhos. Contudo, esta mesma detém uma conotação negativa quando é entendida como um obstáculo à educação, ao controle dos pais sobre as atitudes das crianças e dos jovens.

Na concepção dos pais entrevistados, a ajuda dos filhos é compreendida como um processo educativo que permite a socialização das crianças e jovens no modo de vida local. As atividades desenvolvidas pelos jovens, respeitando-se as condições físicas e as responsabilidades escolares, proporcionam a inserção destes nos valores e culturas locais, sendo um momento de transmissão dos conhecimentos necessários para a continuidade dos modos de vida dos agricultores familiares. Assim, os pais argumentam que os conhecimentos relativos à agricultura devem ser transmitidos aos filhos, concomitantemente aos conhecimentos adquiridos pela escola.

Tem a questão da aprendizagem também. Porque no colégio tem que aprender. A tarefa que o senhor dá no colégio eles vão ter que aprender, e por que que em casa eles não podem aprender? Como se deita uma galinha, como se trata um 
porco, como se tira leite, como se planta uma verdura, como se planta uma mandioca ou uma batata, a batatinha, que é a alimentação do produtor rural (Agricultor familiar, 62 anos).

Desta forma, é a instituição familiar que pode transmitir os conhecimentos da propriedade e que integra as novas gerações aos modos de vida na agricultura. Inserindo as crianças e jovens nos afazeres da propriedade, os pais vão ensinando valores como a responsabilidade, a importância do trabalho e os benefícios de viver no rural. Valores que, segundo eles, não são apresentados na escola. O trabalho caracteriza-se, no imaginário dos agricultores de Agudo, como um processo educativo pelo qual é transmitido o modo de vida local e os conhecimentos necessários para tornar-se futuro agricultor ou agricultora.

A convivência diária das crianças e jovens, tanto nas atividades produtivas quanto nos espaços da casa, é considerada por todos como princípio fundamental para a socialização, popularmente chamada pelos entrevistados de "educação". A relação com a família, o respeito, o trabalho e a busca por melhores condições de vida são valores transmitidos aos filhos no convívio diário da propriedade. Valores que perpassam gerações e que ainda são considerados válidos e indispensáveis à formação dos futuros herdeiros.

Deste modo, a formação do sucessor constitui um objetivo inerente à inserção dos jovens no trabalho da propriedade familiar. Quando o filho acompanha seu pai na roça, ou sua filha auxilia nos afazeres dos arredores da casa, eles vão apropriando-se do modo de vida local, dos saberes e dos fazeres que sustentam a unidade de produção familiar. O processo de socialização no espaço rural, por meio da convivência familiar e comunitária, integra a criança e o jovem ao meio social e cultural dotado de peculiaridades. A infância torna-se, então, a idade mais adequada para transmitir os valores específicos do modo de vida rural, como forma de dar continuidade ao grupo social.

\subsection{Trabalho familiar e trabalho dos filhos}

Os estudos sociais que problematizam as unidades de produção familiar associam a família, a terra e o trabalho como o 'tripé' sob o qual se sustenta a reprodução camponesa. Esses valores são construídos sob a lógica do trabalho familiar, sendo a terra o principal meio de produção das necessidades indispensáveis à reprodução da família. Neste universo, os filhos têm papel fundamental, pois influenciam diretamente a racionalidade econômica sendo parte integrante do núcleo consumidor, bem como de trabalhadores (CHAYANOV, 1974). De fato, os agricultores analisados relatam que sempre trabalharam na agricultura, tanto na produção mercantil de tabaco quanto na produção de autoconsumo. Desta forma, davam continuidade aos ciclos de sobrevivência e reprodução da unidade familiar.

Os agricultores fumicultores de Agudo por nós entrevistados distribuem as principais tarefas do processo produtivo agrícola entre os membros da família. Para fins de análise das atividades das crianças e jovens, além da divisão do trabalho por gênero, procurou-se distribuir em dois grupos etários, dos 6 aos 16 anos e dos 16 aos 18 anos de idade. A Tabela 1 demonstra atividades que, de forma geral, podem ser ligadas à reprodução das famílias (como cuidados com a família, preparo da alimentação, entre outras), separadas pelos membros das famílias. A posição de cada membro é definida pela relação com o(a) chefe de família. Mesmo que em alguns casos a criação de animais apareça entre os principais produtos das famílias dos agricultores entrevistadas, atividades como o trato de animais ou ordenha das vacas também podem ser relacionadas ao sustento da família. Independente de ser para consumo ou para venda, percebe-se que há diferenças no que se refere à posição na hierarquia da família na atividade de ordenhar as vacas, que em $58,97 \%$ dos casos são atribuições das mulheres e em apenas 17,95\% do chefe da família. De forma geral, também se pode relacionar tal atividade com crianças e jovens mais novos, sendo $7,69 \%$ dos casos tanto 
Tabela 1. Realização das atividades ligadas à reprodução familiar entre agricultores familiares de Agudo/RS (\%).

\begin{tabular}{lccccc}
\hline \multicolumn{1}{c}{ Quem realiza } & $\begin{array}{c}\text { Trabalhos } \\
\text { domésticos }\end{array}$ & $\begin{array}{c}\text { Trabalhos na } \\
\text { horta e pomar }\end{array}$ & $\begin{array}{c}\text { Limpeza do } \\
\text { átio e quintal }\end{array}$ & $\begin{array}{c}\text { Ordenha } \\
\text { das vacas }\end{array}$ & $\begin{array}{c}\text { Trato dos } \\
\text { animais }\end{array}$ \\
\hline Chefe & 10,20 & 25,58 & 31,37 & 17,95 & 41,82 \\
Cônjuge & 48,98 & 55,81 & 45,10 & 58,97 & 32,73 \\
Filhos 06 - 16 anos incompletos & 4,08 & 6,98 & 9,80 & 7,69 & 10,91 \\
Filhas 06 - 16 anos incompletos & 24,49 & 2,33 & 5,88 & 7,69 & 3,64 \\
Filhos 16 - 18 anos & 0,00 & 0,00 & 3,92 & 2,56 & 7,27 \\
Filhas 16 - 18 anos & 4,08 & 0,00 & 0,00 & 2,56 & 0,00 \\
Pai & 0,00 & 2,33 & 1,96 & 0,00 & 0,00 \\
Mãe & 8,16 & 4,65 & 0,00 & 2,56 & 1,82 \\
Outros & 0,00 & 2,33 & 0,00 & 0,00 & 0,00 \\
Todos na família & 0,00 & 0,00 & 1,96 & 0,00 & $\mathbf{1 , 8 2}$ \\
Total & $\mathbf{1 0 0}$ & $\mathbf{1 0 0}$ & $\mathbf{1 0 0}$ & $\mathbf{1 0 0}$ & $\mathbf{1 0 0 , 0 0}$ \\
\hline
\end{tabular}

Fonte: Pesquisa Infância, trabalho e relações de gênero na agricultura familiar - CNPq/UFSM/UFRGS/UFG - 2010.

para meninos quanto para meninas, na faixa de 6 a 16 anos. Já no caso do trato aos animais, a maior frequência é encontrada entre os(as) chefes das famílias $(41,82 \%)$, seguido pelos seus cônjuges $(32,73 \%)$ (em $74 \%$ dos casos, os chefes são do sexo masculino). Essa atividade tende a se concentrar, também, entre os filhos do sexo masculino (18,18\%, no total). Em 1,82\% dos casos a família toda é mobilizada para tratar os animais.

Em relação ao trabalho doméstico, tipicamente considerado feminino, nota-se que em $48,98 \%$ dos casos são realizados pelos cônjuges (na maioria, esposas dos chefes das famílias). De fato, em apenas $10,20 \%$ das famílias entrevistadas os chefes auxiliam na realização das atividades domésticas; em 24,49\% das famílias são as filhas dos agricultores familiares entre 6 e 16 anos incompletos que realizam as atividades domésticas. Já a limpeza do pátio e quintal apresenta-se de forma mais distribuída entre o casal, embora também haja predomínio das mulheres cônjuges $(45,10 \%)$ sobre os esposos $(31,37 \%)$. Entre os demais membros das famílias, meninos e homens realizam essas atividades mais frequentemente $(15,69 \%)$.

Além do fumo, os agricultores familiares plantam milho, que é destacado como o segundo principal cultivo, tanto de interesse comercial quanto para fornecimento a suínos, aves e bovinos. Pelo costume, o milho é plantado logo após a colheita do fumo, para aproveitamento residual da adubação efetuada no fumo. $\mathrm{O}$ arroz e o feijão são cultivados pelos agricultores familiares para atendimento do consumo familiar, mas, sempre que possível, vendem os excedentes. Também costumam criar suínos para fornecimento de carne e banha, bem como dispor de alguns bovinos para produção de leite e tração animal. Essas atividades de importância na segurança alimentar e na complementação da renda familiar acabam exigindo dedicação e trabalho coletivo de todos os membros da família.

Vale ressaltar que a ajuda das crianças e jovens torna-se uma necessidade, uma vez que é baixo o número de membros que integram as 27 famílias incluídas na amostra. Conforme o Figura 1, a maior parte das famílias (33,3\%) é composta por quatro indivíduos, isto é, o casal e dois filhos.

A outra parte das famílias $(29,6 \%)$ é formada por apenas três pessoas, o casal e um filho. Por outro lado, as maiores famílias encontradas, compostas por sete integrantes, representam tão somente $7,4 \%$ do total. O baixo número de integrantes das famílias dos agricultores familiares de Agudo implica intensificação do trabalho do casal e na necessidade da ajuda dos filhos para a realização de tarefas, no espaço doméstico, no fumo ou em outras atividades produtivas.

Porém, a ajuda dos filhos com menos de 18 anos torna-se uma necessidade não somente porque a família é pequena, mas também porque o fumo é muito exigente em termos de mão de obra, apresentando tarefas durante o ano inteiro. 
Figura 1. Composição das famílias por número de integrantes.

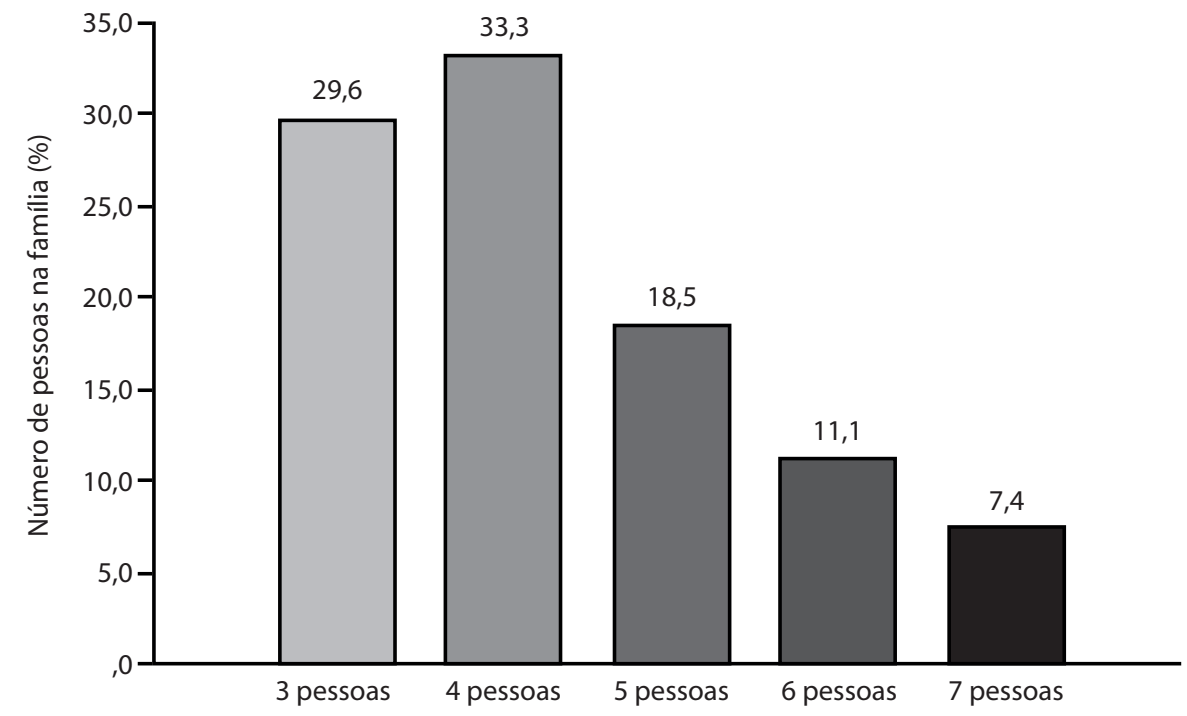

Fonte: Pesquisa Infância, trabalho e relações de gênero na agricultura familiar - CNPq/UFSM/UFRGS/UFG - 2010.

As atividades do fumo começam com a preparação das bandejas de isopor com substrato, distribuição das sementes em cada cavidade das bandejas, irrigação até a germinação, organização das bandejas nos tanques onde as mudas recebem água fertilizada, transplante das mudas na lavoura e aplicação dos tratos culturais para combate das pragas e colheita folha por folha, conforme a maturação. Antes do início da colheita, as famílias limpam as estufas para receber a colheita do fumo. Na sequência, os agricultores familiares colhem folha por folha e, com carroça tracionada por boi ou com trator, as transportam até a estufa. Nesta instalação, organizam o fumo nas varas, carregam a estufa, preparam a lenha no forno e vigiam a noite até atingir o ponto de secagem recomendado. Depois, devem descarregar a estufa, classificar as folhas, formar fardos nas prensas e identificá-los com etiquetas. Antes, porém, precisam limpar os galpões onde fazem a classificação, enfardamento e etiquetagem do fumo, a fim de retirar as sujidades que podem depreciar o fumo ou atrair ratos e outras pragas - como as traças - que furam as folhas depois de dessecadas.

No inverno, quando os agricultores ainda estão classificando as folhas do fumo, já devem começar os preparativos de um novo ciclo produtivo, com o plantio das sementes e formação das mudas necessárias para a próxima safra. Assim, as atividades relacionadas com a produção do fumo, desde o preparo do solo, plantio, tratos culturais até colheita, são realizadas, sobretudo, pelo casal (somando 85,97\%), com maior frequência pelos chefes da família $(47,37 \%)$. O mesmo se repete quando se trata da secagem e classificação do fumo (44,26\% para os chefes das famílias), como indica a Tabela 2. As tarefas ligadas à limpeza e manutenção das instalações da propriedade são realizadas tanto pelos chefes de família $(42,55 \%)$ quanto pela esposa $(46,81 \%)$. Os filhos e filhas não participam muito na realização desse tipo de tarefa, mas essa participação aumenta conforme a idade. Nota-se que a participação dos meninos de 6 até 16 anos incompletos não atinge $5 \%$ em cada um dos casos, enquanto que a participação das filhas na mesma faixa etária não chega a $3 \%$. Os filhos de agricultores com idade acima de 16 anos contribuem para o trabalho familiar em cerca de $8 \%$ dos casos, tanto no preparo do solo, cultivo e colheita quanto na secagem e classificação do fumo, mas o mesmo não se repete quando se trata da limpeza e manutenção das instalações $(2,13 \%)$.

A contratação de trabalhadores assalariados pode ser considerada frequente entre as famílias entrevistadas $(66,7 \%$ do total). Vale ressaltar que 
Tabela 2. Realização das atividades no fumo, município de Agudo/RS (\%).

\begin{tabular}{lccc}
\hline Quem realiza & $\begin{array}{c}\text { Preparo do solo, culti- } \\
\text { vo e colheita }\end{array}$ & $\begin{array}{c}\text { Secagem e classificação } \\
\text { do fumo }\end{array}$ & $\begin{array}{c}\text { Limpeza e manutenção } \\
\text { das instalações }\end{array}$ \\
\hline Chefe & 47,37 & 44,26 & 42,55 \\
Cônjuge & 38,60 & 37,70 & 46,81 \\
Filhos 06 - 16 anos incompletos & 3,51 & 3,28 & 4,26 \\
Filhas 06 - 16 anos incompletos & 0,00 & 1,64 & 2,13 \\
Filhos 16 - 18 anos & 8,77 & 8,20 & 2,13 \\
Filhas 16 - 18 anos & 0,00 & 1,64 & 0,00 \\
Pai & 0,00 & 1,64 & 0,00 \\
Mãe & 0,00 & 1,64 & 2,13 \\
Outros & 1,75 & 0,00 & 0,00 \\
Todos na família & 0,00 & 0,00 & 0,00 \\
Total & $\mathbf{1 0 0}$ & $\mathbf{1 0 0}$ & $\mathbf{1 0 0}$ \\
\hline Fonte: Pesquisa Infância, trabalho e relações de gênero na agricultura familiar - CNPq/UFSM/UFRGS/UFG - 2010.
\end{tabular}

Fonte: Pesquisa Infância, trabalho e relações de gênero na agricultura familiar - CNPq/UFSM/UFRGS/UFG - 2010.

a contratação de assalariados ocorre somente no período de maior necessidade, como na colheita, como forma de ampliação da força de trabalho da família. Entre as famílias que contratam mão de obra assalariada, $55,6 \%$ o fazem entre um e três trabalhadores e $44,4 \%$, entre quatro e seis trabalhadores.

Nem sempre é possível incorporar máquinas na produção do fumo, uma vez que é cultivado em terrenos acidentados ou em encostas de morros, às vezes, íngremes. Dentre as 27 famílias pesquisadas, apenas $29,6 \%$ dispõem de trator e equipamentos agrícolas relacionados, como arado e reboque. A junta de bois para tração animal é encontrada em $88,9 \%$ dos casos, bem como a carroça para transportar a produção e o arado para preparo do solo. A variedade de fumo produzido é Virgínia, cuja secagem precisa de estufas, o que as tornam instalações obrigatórias em todas as famílias fumicultoras. Portanto, as condições técnicas da própria atividade do fumo, a baixa incorporação de tecnologias mecânicas e o relevo acidentado implicam no uso intensivo da mão de obra familiar. No entanto, os agricultores admitem gostar da atividade do fumo e desejam continuar nessa atividade, por ser considerada economicamente compensatória. Os agricultores dominam os procedimentos técnicos do cultivo e processamento das folhas do fumo, uma vez que $37,04 \%$ dos chefes de famílias trabalham nessa atividade entre mais de 21 até 30 anos e 33,33\% mantém-se nessa atividade entre 31 e 40 anos, como mostra a Tabela 3.

Os agricultores afirmam que evitam incorporar os filhos nos trabalhos com o fumo, principalmente nas tarefas realizadas na roça. Mas, ao mesmo tempo, admitem que algumas tarefas desempenhadas nos galpões, como juntar folhas no chão, colocar lenha no forno e auxiliar na classificação, são realizadas, por vezes, com o auxílio dos filhos. Estas tarefas ocorrem, principalmente, no período de férias escolares, quando os filhos têm disponibilidade de tempo e quando há aumento das demandas de força de trabalho na propriedade. Mas a maioria dos pais considera o trabalho no fumo pesado, principalmente em relação à colheita, período em que o trabalho na roça é intenso e cansativo. Ademais, o calor do sol e as chuvas que ocorrem durante a colheita são considerados prejudiciais à saúde. $\mathrm{O}$ trabalho com agrotóxicos também é compreendido como prejudicial, embora garantam que estejam diminuindo o uso desses insumos na lavoura.

Por estas razões, os pais afirmam que a inserção da criança no trabalho da unidade de produção familiar vem tornando-se mais facultativa e dependente, em grande medida, da escolha dos filhos. Os pais aceitam a participação dos filhos mais velhos na propriedade, e eles demonstram mais interesse por permanecer nas 
Tabela 3. Período de tempo de cultivo de fumo dos chefes das famílias.

\begin{tabular}{cc}
\hline Período & Chefes de famílias (\%) \\
\hline $1-10$ anos & 3,7 \\
$11-20$ anos & 22,22 \\
$21-30$ anos & 37,04 \\
$31-40$ anos & 33,33 \\
$41-50$ anos & 3,7 \\
Total & $\mathbf{1 0 0}$ \\
\hline
\end{tabular}

Fonte: Pesquisa Infância, trabalho e relações de gênero na agricultura familiar - CNPq/UFSM/UFRGS/UFG - 2010.

atividades agropecuárias, enquanto que as filhas e os filhos mais novos não demonstram tanto interesse. Assim, as filhas e os filhos mais novos têm, na maioria dos casos, liberdade concedida pela família para não trabalhar com o fumo. Muitos apenas realizam algumas atividades domésticas e nos arredores da propriedade, ou ainda, no cuidado com os irmãos mais novos. Essas tarefas são transferidas, sobretudo, para as meninas, que passam a ser responsáveis pelas atividades domésticas, liberando a mãe para os trabalhos de colheita e processamento do fumo. Entretanto, ainda é frequente a presença dos filhos pequenos na roça, não para o trabalho, mas nos casos em que os pais não têm alguém para cuidar de seus filhos em casa. Assim, as mães podem manter seus filhos próximos, ao mesmo tempo em que realizam as atividades agrícolas.

O trabalho, na perspectiva dos agricultores, interliga a criança e o adolescente à propriedade e à comunidade local, possibilitando a valorização do meio em que vive. Nesse contato cotidiano, as crianças aprendem a valorizar as peculiaridades da convivência nos espaço rural, qualificado pela menor dependência do consumo urbano, pela possibilidade de produzir e consumir alimentos saudáveis, pela proximidade com a vida em comunidade e pelo afastamento dos perigos da violência apresentada pelos meios de comunicação de massa, dentre outras vantagens mencionadas.

\subsection{Infância e escola: a visão dos agricultores fumicultores}

Na compreensão dos agricultores de Agudo, as escolas contribuem para transmitir valores urbanos e, pelo fato de a maioria ser localizada na zona urbana, proporcionam um contato e aprendizado constante do modo de vida urbano, em detrimento da cultura rural local. Apesar destas críticas, os agricultores entrevistados não desmerecem a escola enquanto instituição fundamental para a educação e preparação de um futuro melhor para os filhos. Há um incentivo constante para a escolarização dos filhos, que é alimentado não apenas pela obrigatoriedade da lei, mas pela possibilidade de uma vida melhor na cidade. "Ela tem que estudar e tem que aprender a trabalhar também em alguma coisa. Depois ela que decide o que vai seguir" (Agricultor familiar, 39 anos).

Observa-se a influência crescente da legislação sobre a percepção dos pais em relação à escola, no sentido de responsabilizá-los quanto à necessidade de garantir a frequência escolar dos filhos. Por outro lado, os pais reconhecem que seus filhos têm facilidades de acesso à escola, seja pela gratuidade do ensino, do transporte escolar e de outros incentivos proporcionados pelo poder público municipal ou estadual.

Como parâmetro, os agricultores familiares relacionam as suas próprias experiências para avaliar a escola. A educação escolar fundamental vivenciada pelos agricultores familiares reduzia-se ao domínio da leitura, escrita e cálculos matemáticos. Eles garantem que os pais não tinham por costume incentivar a continuidade dos estudos escolares de seus filhos. A necessidade do trabalho das crianças e o difícil acesso à escola, pelo menos para a maioria das famílias que moravam em locais distantes dos centros urbanos, potencializavam a evasão escolar, assim que as 
crianças completavam a quarta ou quinta série do Ensino Fundamental. As crianças, portanto, frequentavam as séries ofertadas nas escolas rurais próximas às suas propriedades, as quais atendiam as necessidades de conhecimentos segundo as percepções, bem como permitiam que o jovem atuasse na agricultura. Alguns agricultores destacaram que a necessidade de auxiliar nos trabalhos da roça se sobrepunha aos interesses da escolarização, uma vez que a frequência escolar implicava perdas das capacidades produtivas da família. Além disso, era inviável proporcionar a continuidade dos estudos para todos os filhos, visto que as famílias eram grandes e sem recursos para cobrir gastos com a educação escolar. Assim, de acordo com a Figura 2, entre os casais chefes das famílias estudadas, $76,4 \%$ têm o Ensino Fundamental incompleto, 13,7\% têm o Ensino Fundamental completo, 3,9\% têm Ensino Médio incompleto e 1,9\% conseguiram concluir o Ensino Médio, o que indica baixo nível de escolaridade. Em apenas duas famílias, os cônjuges, isto é, as esposas, ingressaram no Ensino Superior, mas não conseguiram concluí-lo.

No contexto atual, os pais entendem que a continuidade da formação escolar, seja em nível médio ou superior, possibilita melhores ocupações laborais no futuro. "Hoje a escola é a base de tudo. Se a gente tivesse a oportunidade que nem nossos filhos tiveram, nós também tava com a caneta atrás da orelha e não aqui" (Agricultor familiar, 50 anos). As referências estão associadas à uma vida mais fácil, trabalho leve e melhor remuneração, observadas nas relações de trabalho urbanas, nas quais a escolarização é fundamental. Assim, a educação escolar é valorizada pelos pais como um passo para melhorar a condição de vida quando comparada ao trabalho na agricultura e, principalmente, com o fumo. Por meio das falas, os agricultores familiares de Agudo admitem que, embora existam vantagens do modo de vida rural, o trabalho assalariado no meio urbano é mais fácil e seguro quando comparado à instabilidade da produção agrícola. O trabalho urbano, desta forma, é avaliado como trabalho leve e mais saudável em relação ao trabalho com o fumo. "Por isso que a gente acha que eles têm que estudar. Pra pelo menos tentar ter uma vida mais fácil, que não precisam trabalhar com o fumo" (Agricultora familiar, 39 anos). Sob este prisma, alguns agricultores familiares entrevistados em Agudo alertam os filhos para que aproveitem a oportunidade de estudar, no sentido de prospectar um futuro mais fácil, menos desgastante. Desejam, desta fora, que os filhos não repitam a mesma sina no trabalho do fumo, conforme depoimento: "Mas pra quem tem condições de estudar e arrumar outro emprego eu acho que é melhor. Tu sofre muito na roça com intempérie" (Agricultor familiar, 50 anos).

Figura 2. Grau de escolaridade dos casais chefes das famílias (\%).

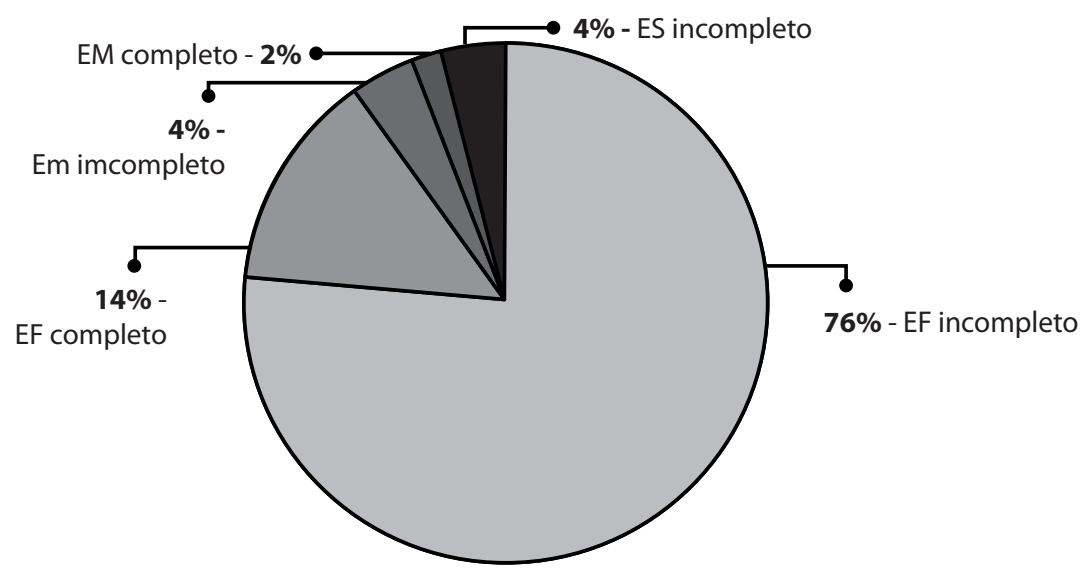

Fonte: Pesquisa Infância, trabalho e relações de gênero na agricultura familiar - CNPq/UFSM/UFRGS/UFG - 2010. 
O sentido da infância preservado na memória dos pais distingue-se, em parte, das atuais compreensões permeadas pelas mudanças na concepção política, social e cultural. Se antes a infância era uma fase da vida de preparação dos futuros sucessores, hoje, a obrigatoriedade da escolarização e a valorização do ensino escolar tornam-se caminhos para a preparação para uma "vida melhor", que pode ser alcançada pelo trabalho no meio urbano. Nota-se que há uma relação contraditória entre a valorização do modo de vida rural e os anseios para o futuro dos filhos, que oscila entre o desejo da permanência dos filhos na propriedade e a percepção do trabalho urbano como possibilidade de uma vida melhor. "Um ou outro tem que assumir a propriedade. Um tem que ficar. Todos estudar não dá. E tem que ter dinheiro pra estudar também" (Agricultora familiar, 36 anos). A aspiração de um sucessor é observada na maioria das falas, mas principalmente entre as famílias com dois ou mais filhos. "Se vocês querem trabalhar fora, tem que estudar. Mas se querem voltar pra lavoura, o estudo também não é em vão." (Agricultor familiar, 48 anos). Contudo, não descartam os benefícios de estudar, mesmo que permaneçam na propriedade. Ressaltam, assim, as possibilidades da escolarização sem a perda dos vínculos com a terra.

Eu quero que eles estudem, mas que não abandonem aqui. Que saibam o que é uma propriedade. Que tenham um vínculo. Porque nós aqui felizmente temos feijão orgânico, arroz orgânico, a mandioca não tem veneno, a batata não tem veneno, o melado não tem veneno, o mel que eu produzo não tem, a carne a gente produz ali dentro do chiqueiro. $\mathrm{O}$ milho que eu consumo, que fica comigo, esse não tem veneno (Agricultor familiar, 35 anos).

Com isso, os conhecimentos transmitidos pela escola não excluem a necessidade de transmissão dos valores familiares e comunitários do rural, para que os filhos possam escolher o futuro desejado.
A liberdade de escolha é permitida na medida em que as crianças e adolescentes tenham conhecimento das opções de vida e de trabalho. $\mathrm{Ou}$ seja, a maioria dos agricultores entrevistados acredita ser necessário que seus filhos conheçam a vida e o trabalho no meio rural, para que possam decidir sobre o seu futuro, seja como trabalhadores urbanos ou rurais. Alguns pais afirmam que o incentivo à não permanência dos filhos na agricultura deve-se à crescente desvalorização da produção agropecuária.

A escola, na maioria dos casos, é significada no processo de qualificação para o mundo do trabalho urbano, mas não referenciada na preparação para o trabalho agrícola. Ou seja, os pais não percebem a escola como instituição responsável pela educação para o trabalho rural, daí que a família deve continuar com sua histórica atribuição educativa dos filhos pelo trabalho coletivo familiar.

\subsection{Trabalho infantil? - os agricultores fumicultores em face da legislação}

Ao longo dos últimos anos, o receio de multa e a crescente coerção das empresas fumageiras têm influenciado na redução do trabalho dos filhos na agricultura. A polêmica em torno da legislação que proíbe o trabalho de menores de 18 anos divide as opiniões. A maioria dos agricultores entrevistados destaca a discordância com a necessidade de uma legislação que fiscaliza a educação dos pais, principalmente em uma situação em que não identificam a presença de "trabalho obrigatório" ou "trabalho escravo", como costumam denominar. Acreditam que esta não é a realidade da agricultura familiar em Agudo ou no Rio Grande do Sul, daí que não há necessidade de uma legislação que interfira sobre a organização do trabalho e da vida familiar. Identificam a necessidade de compreensão das relações de produção familiar por parte dos legisladores para que possam perceber que as leis, por eles criadas, não condizem com a realidade local.

As atividades desenvolvidas pelos filhos são consideradas como educativas. Isto é, elas 
constituem o processo de socialização dos filhos de agricultores familiares, de preparação dos sucessores, de valorização do trabalho da agricultura e de reprodução de seus modos de vida. Os pais entrevistados em Agudo acreditam que a lei impossibilita a formação e a permanência dos sucessores, o que acarretará o fim da agricultura familiar na região. Compreendem que, comos conhecimentos escolares distantes dos valores rurais e com a proibição do trabalho das crianças na agricultura, dificilmente os filhos permanecerão na propriedade. Este é um fator que já vem sendo demonstrado na diminuição e no envelhecimento da população nas comunidades rurais de Agudo. Portanto, reafirmam que o trabalho é fundamental para que aprendam o modo de vida e a sobrevivência no meio rural. Acreditam que, se os filhos não aprenderem a trabalhar na propriedade antes de atingir os 16 anos, dificilmente eles terão interesse de aprender posteriormente. Outrossim, acreditam que não darão valor ao modo de vida rural, caso não tenham contato cotidiano com o trabalho familiar.

Assim, o trabalho é apresentado como parte indispensável da sociabilidade das crianças no meio rural, bem como uma forma de aprendizagem e reprodução de um modo de vida que deve ser valorizado e, ainda, como precaução para os desvios de conduta. Ponto presente nas falas dos agricultores entrevistados é a superproteção das leis como uma das causas dos desvios de conduta dos adolescentes na região. $\mathrm{O}$ contato com as drogas e álcool e a sexualidade prematura são considerados desvios sociais, consequências da liberdade dos adolescentes que não têm ocupação e que desvalorizam os ensinamentos dos pais.

\section{Considerações finais}

Neste artigo demonstramos que a infância é uma construção sociocultural. Isso significa que existe uma multiplicidade de maneiras de entender, expressar, representar e viver a infância, que se transformam ao longo do tempo. Os agricultores familiares que cultivam fumo em
Agudo construíram suas percepções sobre a infância e estratégias de socialização das crianças, a fim de prepará-las para a vida em sociedade e de garantir a reprodução social da família. No entanto, a progressiva integração campo-cidade, a ampliação das instituições escolares e o avanço da legislação de proteção dos direitos das crianças tendem a reduzir a importância do papel da família na educação dos filhos e a construir novas formas de sociabilidade, transformando as visões sobre a infância e o trabalho da criança.

A atual legislação brasileira, expressa na Lista das Piores Formas de Trabalho Infantil, passou a categorizar como "trabalho infantil" todas as tarefas realizadas pelas crianças e adolescentes no cultivo do fumo. A categorização de trabalho infantil está associada aos riscos que todas as tarefas de produção e de processamento do fumo podem causar sobre a saúde e ao pleno desenvolvimento físico e emocional das crianças e adolescentes. Essa legislação segue orientações propugnadas por organismos internacionais, especialmente pela OIT, que defende uma concepção universal no sentido de proibir o trabalho das crianças e de valorizar o ensino escolar. Desta forma, os aparatos jurídicos ampliaram a noção de trabalho infantil, estendendo para diversas atividades que ocorrem no âmbito da agricultura familiar brasileira. Pela legislação vigente, pode-se dizer que os agricultores familiares tornar-se-iam os principais exploradores da força de trabalho infantil no Brasil.

Porém, o estudo demonstrou que existe um confronto entre as concepções sobre a infância e trabalho expressas nos documentos legais e as compreensões historicamente construídas pela cultura transmitida pelas famílias de agricultores. Em Agudo, os agricultores percebem o trabalho da criança como "ajuda" e não como "trabalho infantil", que precisa ser proibido em lei. Sob essa perspectiva, o trabalho das crianças tem um caráter educativo das novas gerações, como parte integrante dos processos de socialização, de formação para a vida e de preparação dos futuros herdeiros. Eles entendem que ensinar a trabalhar é uma atribuição primordial dos pais, ao mesmo 
tempo em que o trabalho é um valor que deve ser transmitido aos filhos, como um legado. Por estes motivos, os pais estão perdendo o seu papel de educadores dos próprios filhos, uma vez que o trabalho sempre foi elemento central nos modos de vida dos agricultores familiares de Agudo. Isso significa que a família está perdendo seu papel histórico na socialização das crianças pelo trabalho, enquanto a instituição escolar adquire maior importância na educação dos filhos dos agricultores.

Por estas razões, os agricultores fumicultores criticam a legislação que protege as crianças e adolescentes e que desautoriza a educação proporcionada pelas famílias. Compreendem que, atualmente, os agricultores familiares têm consciência de proteger os filhos dos trabalhos pesados, para não prejudicar-lhes o desenvolvimento físico e mental, diferente das condições em que foram submetidos em suas infâncias. Desta forma, os pais sentem-se desautorizados a transmitir as regras e valores aos filhos, considerada função da instituição social familiar. A coerção dos meios de comunicação e das empresas fumageiras tende a inibir a participação das crianças nas atividades agrícolas e desautorizar os pais em seus papéis de educadores dos próprios filhos. A ação coercitiva das empresas consiste na assinatura de um Termo de Compromisso, que busca responsabilizar os pais pela frequência escolar de seus filhos, bem como a não utilização do trabalho com o fumo e, principalmente, com agrotóxicos. Caso os pais não observem tais compromissos, poderão ter punições tanto pela agroindústria fumageira, que não comprará o fumo, quanto pelo Conselho Tutelar da Infância e Adolescência, que tomará providências no sentido da observância dos direitos das crianças e adolescentes. Desta forma, as agroindústrias fumageiras aparecem como protetoras das crianças e adolescentes, quando de fato elas transferem uma grande quantidade de trabalhos para o coletivo das famílias, em todas as etapas do processo produtivo, desde o plantio do fumo até a classificação das folhas. Em face do quantitativo do trabalho e dos compromissos assumidos com a agroindústria, as famílias dos agricultores familiares de Agudo, por vezes, recorrem à ajuda dos filhos, como forma de complementação da força familiar. No entanto, os pais não entendem que estão explorando a força de trabalho infantil. Ao contrário, acreditam que estão educando os filhos pelo trabalho.

\section{Referências bibliográficas}

ALONSO, J. E. O. S. e SANT'ANA, F. O. P. Um desenho de avaliação de impacto econômico do Bolsa Família sobre agricultores participantes do PRONAF B baseado em resultados potenciais. In: ENCONTRO NACIONAL DE ECONOMIA, 38, 2010. Anais.... São Paulo: Anpec, 2010.

ALVIM, R. O trabalho infantil e reprodução social: o trabalho das crianças numa fábrica com vila operária. In: SILVA, A. M. (Org.). Condições de vida das camadas populares. Rio de Janeiro: Zahar Editores, 1984.

ANTUNIASSI, M. H. R. Trabalho infantil e escolarização no meio rural. Rio de Janeiro: Zahar Editores, 1983.

ARIÈS, P. História social da criança e da infância. $2^{2}$ Ed. Rio de Janeiro: LTC editora, 1981.

BRANDÃO, C. R. Parentes e Parceiros: Relações de produção e relações de parentesco entre camponeses de Goiás. In: ARANTES, A. A. (et al.). Colcha de Retalhos: Estudos sobre a família no Brasil. 3. Ed. Campinas, SP: Editora da UNICAMP, 1994.

BRASIL. Decreto no 6.481, de 12 de junho de 2008. Regulamenta os artigos 3o, alínea "d", e 4o da Convenção 182 da Organização Internacional do Trabalho (OIT) que trata da proibição das piores formas de trabalho infantil e ação imediata para sua eliminação, aprovada pelo Decreto Legislativo no 178, de 14 de dezembro de 1999, e promulgada pelo Decreto no 3.597, de 12 de setembro de 2000, e dá outras providências.

BRASIL. Ministério do Desenvolvimento Social. Programa Bolsa Família. Disponível em: < http://www. mds.gov.br/bolsafamilia >. Acesso em: 17 set. 2010.

CALDEIRA, C. Menores no meio rural: Trabalho $e$ escolarização. Rio de Janeiro: CBPC/INEP, 1960.

CANDIDO, A. Os parceiros do Rio Bonito: estudo sobre o caipira paulista e a transformação dos seus meios de vida. São Paulo: Livraria Duas Cidades, 1987.

CHAYANOV, A. La organización de la unidad econômica campesina. Buenos Aires: Nueva Visión, 1974. 
DUARTE, G. B., SAMPAIO, B. e SAMPAIO, Y. Programa Bolsa Família: impacto das transferências sobre os gastos com alimentos em famílias rurais. Revista de Economia e Sociologia Rural, Piracicaba, v. 47, n. 04, p. 903-918, out/dez, 2009.

FERRO, A. e KASSOUF, A. L. Avaliação do impacto dos programas de bolsa escola no trabalho infantil no Brasil. Revista Pesquisa e Planejamento Econômico, vol. 35, n. 3, 2005.

FERRO, A. e KASSOUF, A. L. Efeitos do aumento da idade mínima legal no trabalho de brasileiros de 14 a 15 anos. Revista de Economia e Sociologia Rural, Rio de Janeiro, v. 43, n. 02, p. 307-329, jan./mar., 2007.

FUKUI, L. F. G. Sertão e bairro rural: parentesco e família entre sitiantes tradicionais. São Paulo: Ática, 1979.

GARCIA Jr., A. R. Terra de trabalho: trabalho familiar de pequenos produtores. Rio de Janeiro: Paz e terra: 1983.

KASSOUF, A. L. O que conhecemos sobre o trabalho infantil? Revista Nova Economia, Belo Horizonte, v. 17, n. 2, p. 323-350, maio/ago., 2007.

KASSOUF, A. L. O trabalho infantil em cinco estados brasileiros. Brasília: OIT, 2004.

KASSOUF, A. L. e FERRO, A. R. O trabalho infantil no ramo agrícola brasileiro. Brasília: OIT, 2004.

KASSOUF, A. L. e SANTOS, M. J. Trabalho infantil no meio rural brasileiro: evidências sobre o "Paradoxo da Riqueza”. Economia Aplicada, v. 14, p. 363-376, 2010.

MARIN, J. O. B. Trabalho infantil: necessidade, valor e exclusão social. Brasília: Plano, Goiânia, Editora da UFG, 2006.

MARIN, J. O. B. e MARIN, E. F. B. A internacionalização dos direitos das crianças e suas repercussões na regulação jurídica e combate ao trabalho infantil no Brasil. Revista Latinoamericana de Estudios del Trabajo, v. 20, p. 129-154, 2008. Disponível em: <http://www.izt. uam.mx.alast/index_archivos/page1631.htm $>$. Acesso em: 17 set. 2010.

MARIN, J. O. B. e VENDRUSCOLO, R. Infância e trabalho nas unidades de produção familiar In: ENCONTRO DA REDE DE ESTUDOS RURAIS, 4., 2010. Anais... Curitiba: UFPR, 2010.

MARTINS, J. S. Capitalismo e tradicionalismo: estudos sobre as contradições da sociedade agrária no Brasil. São Paulo: Pioneira, 1975.

MARTINS, J. S. Regimar e seus amigos: a criança na luta pela terra e pela vida. In: MARTINS, J. de S. (coord.). O massacre dos inocentes: a criança sem infância no Brasil. São Paulo: Editora HUCITEC, 1991, p. 51-80.

MARX, K. O capital: crítica da economia política. São Paulo: Difel, 1982.
MOURA, E. B. B. Infância operária e acidente de trabalho em São Paulo. In: DEL PRIORE, M. (Org.). História da criança no Brasil. São Paulo: Contexto, 1991.

NEVES, D. P. A perversão do trabalho infantil: lógicas sociais e alternativas de prevenção. Niterói: Intertexto, 1999.

NICOLELLA, A. C., KASSOUF, A. L. e BARROS, A. M. O Impacto do trabalho infantil no setor agrícola sobre a saúde. Revista de Economia e Sociologia Rural, v. 46, n. 3, p. 673-701, 2008.

OIT. Convenção n. 182 - Convenção sobre proibição das piores formas de trabalho infantil e ação imediata para sua eliminação. Genebra: OIT, 1999. Disponível em: < http:// www.oitbrasil.org.br/info/download/conv_182.pdf $>$. Acesso em: 20 abr. 2010.

OIT. Organização Internacional do Trabalho. O trabalho infantil no ramo agrícola brasileiro. KASSOUF, A. L. (Coord.) Brasília: OIT, 2004.

PEDREIRA, L A. Peti: de(sen)volvendo a infância perdida? 2006. 151 f. Dissertação (Mestrado) - Universidade do Estado da Bahia. Departamento de Educação. Programa de Pós-graduação em Educação e Contemporaneidade, Salvador, 2006.

PONTILI, R. M. e KASSOUF, A. L. Fatores que afetam a frequência e o atraso escolar, nos meios urbano e rural, de São Paulo e Pernambuco. Revista de Economia e Sociologia Rural, Rio de Janeiro, v. 45, n. 01, p. 027-047, jan./mar., 2007.

QUEIROZ, M. I. P. Bairros Rurais Paulistas. In: Revista do Museu Paulista. v. XVII. São Paulo, 1967.

SANTOS, J. V. T. Colonos do vinho: estudo sobre a subordinação do trabalho camponês ao capital. São Paulo: Editora HUCITEC, 1984.

SCHNEIDER, S. O trabalho infantil no ramo agrícola brasileiro: uma apreciação do estudo da OIT. Porto Alegre: Fetag-RS, Série Documentos n. 01, jan., 2005.

SCHNEIDER, S. Reflexões sobre diversidade e diversificação: agricultura, formas familiares e desenvolvimento rural. Revista Ruris, Campinas/SP, v. 4, n.1, mar.; 2010.

SOUZA, R. P. Convenção - Quadro para Controle do Tabaco: reflexões sobre o futuro da fumicultura brasileira. In: CONGRESSO DA SOCIEDADE BRASILEIRA DE ECONOMIA, ADMINISTRAÇÃO E SOCIOLOGIA RURAL, 47., 2009, Anais.... Porto Alegre: SOBER, 2009.

THOMPSON, E. P. A formação da classe operária inglesa. V. II. Rio de Janeiro: Paz e Terra, 1987.

WOORTMANN, E. e WOORTMANN, K. O trabalho da terra: a lógica simbólica da lavoura camponesa. Brasília: Editora UNB, 1997. 
